\title{
A study on controlling Setaria viridis and Corchorus olitorius associated with Phaseolus vulgaris growth using natural extracts of Chenopodium album
}

\author{
Kowthar Gad El-Rokiek ${ }^{*}$, Samia Amin Saad El-Din ${ }^{1}$, Abeer Nasr Shehata ${ }^{2}$ \\ Salma Ahmed Mahmoud El-Sawi
}

\author{
${ }^{1}$ Botany Department, National Research Centre, Dokki, P.O. Box 12622 Cairo, Egypt \\ ${ }^{2}$ Biochemistry Department, National Research Centre, Dokki, P.O. Box 12622 Cairo, Egypt \\ ${ }^{3}$ Pharmacognosy Department, National Research Centre, Dokki, P.O. Box 12622 Cairo, Egypt
}

Received: November 14, 2015

Accepted: June 14, 2016

\begin{abstract}
The effects of water extracts of Chenopodium album leaves and roots on the growth of grass weed (Setaria viridis) and broad leaf weed (Corchorus olitorius) grown with beans (Phaseolus vulgaris) in greenhouse pots were studied in the National Research Centre, Giza, Egypt. In this experiment fresh leaf and root extracts and their corresponding dry leaf and root extracts at different concentrations were used. There were significant inhibitions in the dry weights of S. viridis and C. olitorius by all extracts at the flowering stage of beans and at harvest. The inhibition effect of all C. album extracts on both weeds (dry weight/pot) depended on the extracted plant organ (leaf or root), its fresh or dry form as well as its concentrations. The inhibition caused by the leaf extract was much higher on weed growth than that of root extract. A higher concentration of fresh leaf extract $(25 \%)$ had the highest significant inhibition effect. The results also indicated that $C$. olitorius was more sensitive to the extracts than S. viridis. On the other hand, the inhibition effect of the extracts on the growth of both weeds was accompanied by increased bean growth and yield/plant. The analysis of both leaf and root extracts of $C$. album revealed that the total content of polyphenols and flavonoids in the leaf extract was more than triple that of the root extract. The results suggested that the fresh leaf extract of $C$. album may be a possible tool for the development of weed control using natural herbicides.
\end{abstract}

Key words: beans, Chenopodium album, Corchorus olitorius, flavonoids, leaf extract, polyphenols, root extract

\section{Introduction}

The bean (Phaseolus vulgaris L.) is one of the most important food legumes for direct human consumption. The consumption of the common bean in the world made up $50 \%$ of all other legumes consumed (Graham et al. 2003). It contains large amounts of protein, phosphorus, iron, vita$\min \mathrm{B}$, fiber, and is free of cholesterol. Weeds compete with crop plants for light, water and minerals causing damage to crop yield (Lehoczky and Reisinger 2003). El-Rokiek et al. (2013) recorded more than $47 \%$ reduction in bean yield due to weed competition. Therefore, weeds are considered to be an important factor in reducing crop yield.

Allelopathic plants produced allelochemicals that may be released into the surrounding environment in high amounts, affecting neighboring species (Weston 1996; Singh et al. 2003 and 2005). Chenopodium album L. is a widespread weed in field crops as well as orchards in Egypt. This weed is one of many noxious weeds that possess allelopathic potential to affect plant growth and crop production (Hamayun et al. 2005; Singh et al. 2003 and 2009; El-Rokiek et al. 2010). Chenopodium album has been reported to possess high allelopathic activity against corn, bean and wheat (Szaryas 2000; Alam et al. 2002; Bagheri et al. 2013). Aqueous leachates of C. album plant parts (roots, whole plants and leaves) affect the germination and initial growth of Cassia occidentalis L. (a weed) and Phaseolus aureus (a crop) by significantly decreasing plant height, biomass, chlorophyll and protein content (Batish et al. 2006). Rezaie and Yarnia (2009) reported that C. album extract severely reduced root and shoot dry weight, root length and biomass as well as crop establishment of safflower. The aim of the present experiment was to study the allelopathic effect of leaf and root extracts of C. album on the growth of two infested weeds, Corchorus olitorius L. (broad leaf weed) and Setaria viridis (L.) P. Beauv. (grass weed) grown with beans.

\section{Materials and Methods}

\section{Collection of Chenopodium album}

Preparation of dry leaf and root materials

Chenopodium album was collected from Egyptian fields and gardens at the flowering stage. The leaves and roots 
were separated, washed with tap water several times, then with distilled water to remove dust. Fresh weight of leaves at $25 \mathrm{~g}$ corresponded to $5.33 \mathrm{~g}$ dry leaf and fresh weight of root at $25 \mathrm{~g}$ corresponded to $9.90 \mathrm{~g}$ dry root. All the quantities needed for the experiment were calculated and weighed. The separated parts were left in the shade till dry. Then they were powdered and kept till use.

\section{Preparation of fresh leaves, roots and the water extract}

Chenopodium album was collected as previously mentioned. The leaves and roots of $C$. album were separated (750 $\mathrm{g}$ for each), washed with tap water several times, then with distilled water to remove dust. Next, they were cut into fine particles and transferred to labeled beakers. Three liters of distilled water were added, and allowed to soak for $24 \mathrm{~h}$. Then the produced leaf and root extracts were collected and filtered through a very fine mesh and pressed carefully for complete extraction. The produced extracts (leaf and root) were at $25 \%$ concentration and then diluted with distilled water, to a concentration of $12.5 \%$ for each extract. This step was repeated with the corresponding dry, finely powdered leaves and roots that had previously been prepared. The process of extraction was repeated according to need so; the extracts were fresh.

\section{Growing beans and weeds}

The study was carried out in the greenhouse of the National Research Centre, Dokki, Cairo, during two successive seasons, March, 2013 and March, 2014. Bean seeds cv. Giza 3 were used in the experiment. The pots, $30 \mathrm{~cm}$ in diameter and $30 \mathrm{~cm}$ in height, contained equal amounts of sieved soil (2: $1 \mathrm{v} / \mathrm{v}$ clay and sand). Bean seeds were selected for uniformity by choosing those of equal size and with the same colour. Seeds of beans were sown $2 \mathrm{~cm}$ deep, and germinated at average maximum and minimum temperatures of $27.5 \pm 1$ and $15.5 \pm 1^{\circ} \mathrm{C}$. All pots were infested with the same weight of seeds $(0.03 \mathrm{~g})$ of $C$. olitorius and $S$. viridis and mixed thoroughly at a depth of $2 \mathrm{~cm}$ in the soil. Beans and weeds were sown at the same time. The cultivated beans were thinned two weeks after sowing so that three homogeneous seedlings were left per pot. Ammonium nitrate and super phosphate $(2: 1 \mathrm{w} / \mathrm{w})$ were added to each pot during plant growth. The prepared fresh leaf and root extracts were used at concentrations of 12.5 and $25 \%$ and the corresponding dry weights of leaf were 2.66 and $5.33 \mathrm{~g}$ and of the root 4.95 and 9.90 g extracts.

The pots were sprayed three times during the three weeks to obtain maximum effect, starting with 15-day-old plants. The experiment consisted of 13 treatments including: five untreated controls, S. viridis only, C. olitorius only, S. viridis and C. olitorius, only beans and beans with two weed species (unweeded treatment). The other eight treatments were: fresh leaf extract at two concentrations, and corresponding dry leaf extract at two concentrations, fresh root extract at two concentrations and corresponding dry root extract at two concentrations. The pots contained beans and the two weed species were sprayed with the fresh leaf and root extracts of C. album at 12.5 and 25\% and their correspondence in dry weight $(2.66$ and $5.33 \mathrm{~g}$ for dry leaf extract and 4.95 and $9.90 \mathrm{~g}$ for dry root extract). Each pot was sprayed with $150 \mathrm{ml}$ of the extract. Each treatment was represented by nine pots. The pots were distributed in a completely randomized design.

\section{Weeds and beans data}

Weeds

Weed samples were taken from each of the three pots at the flowering stage and at harvest (all weed samples in each pot were pulled up). They were then oven dried at $60^{\circ} \mathrm{C}$ for determination of dry weight (g/pot). The dry weights of grown weeds were recorded.

\section{Beans data}

For the three plants in each pot that were pulled up (three pots in each stage), plant height, number of leaves, and number of flowers as well as dry weight (g/plant) were recorded at the flowering stage for each individual crop plant. At harvest, the number and weight of green pods per plant were taken from three pots of each treatment and the other three pots were left for dry yield. The number of dry pods/plant, the number of seeds/pod, weight of seeds/plant and weight of 100 seeds were recorded in dry yield.

\section{Chemical analysis of Chenopodium album extracts}

\section{Preparation of plant extracts}

Plant extracts were prepared according to a standard protocol. Prepared plant material (10 g) was transferred to dark-coloured flasks and mixed with $200 \mathrm{ml}$ methanol, and stored at room temperature. After $24 \mathrm{~h}$, infusions were filtered through Whatman No. 1 filter paper and the residue was re-extracted with an equal volume of solvents. After $48 \mathrm{~h}$, the process was repeated. Combined supernatants were evaporated to dryness under vacuum at $40^{\circ} \mathrm{C}$ using a Rotary evaporator. The obtained extracts were kept in sterile sample tubes and stored in a refrigerator at $4^{\circ} \mathrm{C}$ (Stanković 2011).

\section{Determination of total phenolic contents in the plant extracts}

The concentration of phenolics in the plant extracts was determined spectrophotometrically (Singleton et al. 1999). A methanolic solution of the extract, at a concentration of $1 \mathrm{mg} \cdot \mathrm{ml}^{-1}$, was used in the analysis. The reaction mixture was prepared by mixing $0.5 \mathrm{ml}$ of the methanolic solution of the extract, $2.5 \mathrm{ml}$ of $10 \%$ Folin-Ciocalteu's reagent dissolved in water and $2.5 \mathrm{ml} 7.5 \% \mathrm{NaHCO}_{3}$. Blank was concomitantly prepared, containing $0.5 \mathrm{ml}$ methanol, $2.5 \mathrm{ml} \mathrm{10 \%} \mathrm{Folin-Ciocalteu's} \mathrm{reagent} \mathrm{dissolved} \mathrm{in} \mathrm{water}$ and $2.5 \mathrm{ml}$ of $7.5 \%$ of $\mathrm{NaHCO}_{3}$. The samples were thereafter incubated in a thermostat at $45^{\circ} \mathrm{C}$ for $45 \mathrm{~min}$. The absorbance was determined using a spectrophotometer at $\lambda_{\max }=765 \mathrm{~nm}$. The samples were prepared in triplicate 
for each analysis and the mean value of absorbance was obtained. The same procedure was repeated for the standard solution of gallic acid and the calibration line was construed. Based on the measured absorbance, the concentration of phenolics was read $\left(\mathrm{mg} \cdot \mathrm{ml}^{-1}\right)$ from the calibration line, then the content of phenolics in the extracts was expressed in terms of gallic acid equivalent (mg of $\mathrm{GA} / \mathrm{g}$ of sample).

\section{Determination of flavonoid concentrations in the plant extracts}

The content of flavonoids in the examined plant extracts was determined spectrophotometricaly (Quettier et al. 2000). The sample contained $1 \mathrm{ml}$ of the methanol solution of the extract at a concentration of $1 \mathrm{mg} \cdot \mathrm{ml}^{-1}$ and $1 \mathrm{ml}$ of $2 \% \mathrm{AlCl}_{3}$ solution dissolved in methanol. The samples were incubated for an hour at room temperature. The absorbance was determined using a spectrophotometer at $\lambda_{\max }=415 \mathrm{~nm}$. The samples were prepared in triplicate for each analysis and the mean value of absorbance was obtained. The same procedure was repeated for the standard solution of rutin and the calibration line was construed. Based on the measured absorbance, the concentration of flavonoids was read $\left(\mathrm{mg} \cdot \mathrm{ml}^{-1}\right)$ on the calibration line, then, the content of flavonoids in the extracts was expressed in terms of rutin equivalent $\left(\mathrm{mg}\right.$ of $\mathrm{RU} \cdot \mathrm{g}^{-1}$ of sample).

\section{Statistical analysis}

The data were statistically analyzed using analysis of variance (ANOVA), the mean values were compared at $5 \%$ level of significance (Snedecor and Cochran 1980).

\section{Results}

\section{Effect of Chenopodium album extracts on weeds}

The results in Table 1 show that different extract treatments of Chenopodium reduced the dry weight of both $S$. viridis and C. olitorius in comparison to two untreated weed species associated with beans (mixed control). The reduction was recorded at the flowering stage and at harvest. The reduction in the dry weight of the two weeds was consistent during the experimental period with all treatments. The reduction in C. olitorius was higher than S. viridis. At harvest, S. viridis was reduced by about $90.3 \%$ with the fresh leaf extract $(25 \%)$ compared to untreated weeds associated with beans. The corresponding result in C. olitorius was about 95.1\% (Table 1).

\section{Effect of Chenopodium album extracts on bean growth and yield}

\section{Growth parameters}

The results in Table 2 reveal significant increases in plant height of beans due to spraying with fresh and dry leaf extract as well as fresh and dry root extract of C. album. The increase in plant height at the flowering stage as well as at harvest reached maximum value by using $25 \%$ leaf extract. The number of leaves/plant as well as the number of flowers/plant increased significantly compared to the untreated, unweeded control (weeds associated with beans) by all extracts at both the flowering stage and harvest. The fresh leaf extract was more effective. The most significant increase in dry weight at both flowering and harvest was recorded with fresh leaf extract $(25 \%)$ as compared to the untreated, unweeded control.

Table 1. Effect of Chenopodium album extracts on dry weight of Setaria viridis and Corchorus olitorius in beans (average of the two seasons)

\begin{tabular}{|c|c|c|c|c|c|}
\hline \multirow{3}{*}{ Treatment } & \multirow{3}{*}{$\begin{array}{c}\text { Extract } \\
\text { concentration } \\
{[\%]}\end{array}$} & \multicolumn{4}{|c|}{ Dry weight [g/pot] } \\
\hline & & \multicolumn{2}{|c|}{ at flowering } & \multicolumn{2}{|c|}{ at harvest } \\
\hline & & S. viridis & C. olitorius & S. viridis & C. olitorius \\
\hline Setaria viridis & - & $1.385 \mathrm{a}$ & $\mathrm{N} / \mathrm{A}$ & $3.605 \mathrm{a}$ & $\mathrm{N} / \mathrm{A}$ \\
\hline Corchorus olitorius & - & N/A & $0.838 \mathrm{a}$ & N/A & $5.756 \mathrm{a}$ \\
\hline S. viridis + C. olitorius & - & $1.277 \mathrm{~b}$ & $0.733 \mathrm{~b}$ & $3.492 \mathrm{a}$ & $4.952 \mathrm{~b}$ \\
\hline Beans only & - & N/A & N/A & N/A & N/A \\
\hline Beans $+S$. viridis $+C$. olitorius & - & $0.815 \mathrm{c}$ & $0.682 \mathrm{bc}$ & $3.267 \mathrm{~b}$ & $4.352 \mathrm{c}$ \\
\hline \multirow{2}{*}{$\begin{array}{l}\text { Beans }+ \text { S. viridis }+ \text { C. olitorius } \\
+ \text { C. album leaves fresh }\end{array}$} & 12.50 & $0.392 \mathrm{i}$ & $0.174 \mathrm{f}$ & $0.904 \mathrm{~g}$ & $0.260 \mathrm{f}$ \\
\hline & 25.00 & $0.323 \mathrm{j}$ & $0.113 \mathrm{f}$ & $0.318 \mathrm{~h}$ & $0.212 \mathrm{f}$ \\
\hline \multirow{2}{*}{$\begin{array}{l}\text { Beans }+ \text { S. viridis }+ \text { C. olitorius } \\
+ \text { C. album leaves dry }\end{array}$} & 2.66 & $0.546 \mathrm{~g}$ & $0.435 \mathrm{e}$ & $1.948 \mathrm{e}$ & $0.623 \mathrm{e}$ \\
\hline & 5.33 & $0.433 \mathrm{~h}$ & $0.190 \mathrm{f}$ & $0.966 \mathrm{~g}$ & 0.486 ef \\
\hline \multirow{2}{*}{$\begin{array}{l}\text { Beans }+S . \text { viridis }+C \text {. olitorius } \\
+C . \text { album root fresh }\end{array}$} & 12.50 & $0.723 \mathrm{e}$ & $0.453 \mathrm{de}$ & $2.112 \mathrm{e}$ & $1.940 \mathrm{~d}$ \\
\hline & 25.00 & $0.650 \mathrm{f}$ & $0.527 \mathrm{~d}$ & $1.614 \mathrm{f}$ & $1.557 \mathrm{~d}$ \\
\hline \multirow{2}{*}{$\begin{array}{l}\text { Beans }+S . \text { viridis }+ \text { C. olitorius } \\
+ \text { C. album root dry }\end{array}$} & 4.95 & $0.781 \mathrm{~d}$ & $0.642 \mathrm{c}$ & $2.863 c$ & $1.833 \mathrm{~d}$ \\
\hline & 9.90 & $0.733 \mathrm{e}$ & $0.611 \mathrm{c}$ & $2.399 \mathrm{~d}$ & $1.693 \mathrm{~d}$ \\
\hline LSD at $5 \%$ & & 0.029 & 0.082 & 0.216 & 0.386 \\
\hline
\end{tabular}

$\mathrm{N} / \mathrm{A}=$ not applicable; mean values in the same column for each trait followed by the same lower-case letter are not significantly according to Fisher's Least Significant Difference (LSD) test at $\mathrm{p} \leq 0.05$ 
Table 2. Effect of Chenopodium album extracts on different growth parameters of beans

\begin{tabular}{|c|c|c|c|c|c|c|c|c|}
\hline \multirow[b]{2}{*}{ Treatment } & \multirow[b]{2}{*}{$\begin{array}{c}\text { Extract } \\
\text { concentration } \\
{[\%]}\end{array}$} & \multicolumn{4}{|c|}{ At flowering } & \multicolumn{3}{|c|}{ At harvest } \\
\hline & & $\begin{array}{l}\text { plant } \\
\text { height } \\
{[\mathrm{cm}]}\end{array}$ & $\begin{array}{l}\text { number } \\
\text { of leaves/ } \\
\text { plant }\end{array}$ & $\begin{array}{l}\text { number } \\
\text { of } \\
\text { flowers/ } \\
\text { plant }\end{array}$ & $\begin{array}{c}\text { dry } \\
\text { weight/ } \\
\text { plant }[g]\end{array}$ & $\begin{array}{l}\text { plant } \\
\text { height } \\
{[\mathrm{cm}]}\end{array}$ & $\begin{array}{l}\text { number } \\
\text { of leaves } \\
\text { /plant }\end{array}$ & $\begin{array}{c}\text { dry } \\
\text { weight/ } \\
\text { plant [g] }\end{array}$ \\
\hline Setaria viridis & - & N/A & N/A & N/A & N/A & N/A & N/A & N/A \\
\hline Corchorus olitorius & - & N/A & N/A & N/A & N/A & N/A & N/A & N/A \\
\hline S. viridis + C. olitorius & - & N/A & N/A & N/A & N/A & N/A & N/A & N/A \\
\hline Beans only & - & $42.16 \mathrm{~b}$ & $7.00 \mathrm{a}$ & $6.00 \mathrm{~b}$ & $2.331 \mathrm{a}$ & $55.66 \mathrm{~b}$ & $15.00 \mathrm{a}$ & $6.322 \mathrm{a}$ \\
\hline Beans $+S$. viridis $+C$. olitorius & - & $34.00 \mathrm{f}$ & $3.83 \mathrm{f}$ & $3.00 \mathrm{e}$ & $1.238 \mathrm{~d}$ & $41.26 \mathrm{f}$ & $5.66 \mathrm{f}$ & $2.915 \mathrm{~g}$ \\
\hline \multirow{2}{*}{$\begin{array}{l}\text { Beans }+S . \text { viridis }+C \text {. olitorius } \\
+C . \text { album leaves fresh }\end{array}$} & 12.50 & $40.00 \mathrm{c}$ & $4.72 \mathrm{~d}$ & $6.50 \mathrm{~b}$ & $1.753 \mathrm{c}$ & $53.50 \mathrm{bc}$ & $9.66 \mathrm{~cd}$ & $5.393 \mathrm{~d}$ \\
\hline & 25.00 & $43.66 \mathrm{a}$ & $6.16 \mathrm{~b}$ & $8.16 \mathrm{a}$ & $2.190 \mathrm{ab}$ & $60.00 \mathrm{a}$ & $15.50 \mathrm{a}$ & $6.516 \mathrm{a}$ \\
\hline \multirow{2}{*}{$\begin{array}{l}\text { Beans }+S . \text { viridis }+C . \text { olitorius } \\
+C . \text { album leaves dry }\end{array}$} & 2.66 & $35.41 \mathrm{e}$ & $4.80 \mathrm{~d}$ & $5.50 \mathrm{c}$ & $1.575 \mathrm{c}$ & $51.33 \mathrm{~cd}$ & $9.16 \mathrm{~d}$ & $5.061 \mathrm{e}$ \\
\hline & 5.33 & $38.83 \mathrm{~cd}$ & $5.22 \mathrm{c}$ & $6.50 \mathrm{~b}$ & $2.044 \mathrm{~b}$ & $53.00 \mathrm{c}$ & $11.25 \mathrm{~b}$ & $6.019 \mathrm{~b}$ \\
\hline \multirow{2}{*}{$\begin{array}{l}\text { Beans }+S \text {. viridis }+C \text {. olitorius } \\
+C . \text { album root fresh }\end{array}$} & 12.50 & $38.08 \mathrm{~d}$ & $4.72 \mathrm{~d}$ & $5.00 \mathrm{~d}$ & $1.713 \mathrm{c}$ & $50.00 \mathrm{~d}$ & $9.26 \mathrm{~d}$ & $4.926 \mathrm{e}$ \\
\hline & 25.00 & $39.16 \mathrm{~cd}$ & $6.00 \mathrm{~b}$ & $5.75 \mathrm{c}$ & $1.796 \mathrm{bc}$ & $51.00 \mathrm{~cd}$ & $10.33 \mathrm{c}$ & $5.680 \mathrm{c}$ \\
\hline \multirow{2}{*}{$\begin{array}{l}\text { Beans }+S . \text { viridis }+ \text { C. olitorius } \\
+ \text { C. album root dry }\end{array}$} & 4.95 & $36.48 \mathrm{e}$ & $4.33 \mathrm{e}$ & $4.53 \mathrm{~d}$ & $1.653 \mathrm{c}$ & $47.10 \mathrm{e}$ & $7.00 \mathrm{e}$ & $4.569 \mathrm{f}$ \\
\hline & 9.90 & $38.10 \mathrm{~d}$ & $5.13 \mathrm{c}$ & $5.46 \mathrm{~cd}$ & $1.733 \mathrm{c}$ & $49.26 \mathrm{de}$ & $7.66 \mathrm{e}$ & $4.829 \mathrm{e}$ \\
\hline LSD at $5 \%$ & & 1.36 & 0.33 & 0.71 & 0.269 & 2.29 & 0.88 & 0.281 \\
\hline
\end{tabular}

$\mathrm{N} / \mathrm{A}=$ not applicable; mean values in the same column for each trait followed by the same lower-case letter are not significantly according to Fisher's Least Significant Difference (LSD) test at $\mathrm{p} \leq 0.05$

\section{Green and dry yield of beans plant}

Chenopodium album leaf and root extracts induced significant increases in the number of green pods/plant as well as the weight of green pods/plant of beans in comparison to the untreated, unweeded control (Table 3). There was an observable significant increase with a higher concentration of fresh leaf extract and corresponding dry leaf extract. In general, the increase in number and weight of green pod/plant caused by fresh leaf and root extract was remarkable, especially when $25 \%$ leaf extract was used.

The effect of leaf and root extracts of C. album on the number of dry pods/plant as well as the number of seeds/ pod of beans showed good results when compared to the untreated, unweeded control (Table 3). The ability of $C$. album extract to increase yield/plant was variable depending on the type of extract, whether it was fresh or dry, leaf or root as well as its concentration. In general, fresh leaf and root extracts were significantly more effective. The increase in seed weight/plant (seed yield/plant) was concentration dependent. Increasing the concentration of the extract from 12.5 to $25 \%$ caused a more significant increase in bean yield/plant. Spraying fresh leaf extract at $25 \%$ was the most effective. A similar trend was obtained in the weight of 100 seeds.

Table 3. Effect of Chenopodium album extracts on yield and yield components of beans

\begin{tabular}{|c|c|c|c|c|c|c|c|}
\hline Treatment & $\begin{array}{c}\text { Extract } \\
\text { concentration } \\
{[\%]} \\
\end{array}$ & $\begin{array}{l}\text { Number of } \\
\text { green pods } \\
\text { /plant }\end{array}$ & $\begin{array}{l}\text { Weight of } \\
\text { green pods/ } \\
\text { plant }[\mathrm{g}]\end{array}$ & $\begin{array}{l}\text { Number of } \\
\text { dry pods }\end{array}$ & $\begin{array}{l}\text { Number of } \\
\text { seeds/pod }\end{array}$ & $\begin{array}{l}\text { Seed yield/ } \\
\text { plant [g] }\end{array}$ & $\begin{array}{l}\text { Weight of } \\
100 \text { seeds } \\
\text { [g] }\end{array}$ \\
\hline Setaria viridis & - & N/A & N/A & N/A & N/A & N/A & N/A \\
\hline Corchorus olitorius & - & N/A & N/A & N/A & N/A & $\mathrm{N} / \mathrm{A}$ & N/A \\
\hline S. viridis + C. olitorius & - & N/A & N/A & N/A & N/A & N/A & N/A \\
\hline Beans only & - & $6.53 c$ & $15.20 \mathrm{bc}$ & $7.16 \mathrm{a}$ & $5.00 \mathrm{a}$ & $12.29 \mathrm{~b}$ & $33.82 \mathrm{a}$ \\
\hline Beans $+S$. viridis $+C$. olitorius & - & $4.56 \mathrm{f}$ & $7.30 \mathrm{f}$ & $4.83 \mathrm{e}$ & $2.55 \mathrm{e}$ & $6.13 \mathrm{f}$ & $21.78 \mathrm{f}$ \\
\hline \multirow{2}{*}{$\begin{array}{l}\text { Beans }+ \text { S. viridis }+ \text { C. olitorius } \\
+ \text { C. album leaves fresh }\end{array}$} & 12.50 & $5.00 \mathrm{e}$ & $14.43 \mathrm{c}$ & $5.10 \mathrm{de}$ & $3.16 \mathrm{c}$ & $8.70 \mathrm{de}$ & $30.28 \mathrm{~b}$ \\
\hline & 25.00 & $7.50 \mathrm{a}$ & $18.56 \mathrm{a}$ & $7.30 \mathrm{a}$ & $4.55 \mathrm{~b}$ & $14.23 \mathrm{a}$ & $35.40 \mathrm{a}$ \\
\hline \multirow{2}{*}{$\begin{array}{l}\text { Beans }+S . \text { viridis }+C . \text { olitorius } \\
+C . \text { album leaves dry }\end{array}$} & 2.66 & $5.00 \mathrm{e}$ & $10.76 \mathrm{e}$ & $5.16 \mathrm{de}$ & $3.00 \mathrm{~d}$ & $7.80 \mathrm{e}$ & $28.07 \mathrm{~cd}$ \\
\hline & 5.33 & $7.00 \mathrm{~b}$ & $15.86 \mathrm{~b}$ & $6.73 \mathrm{~b}$ & $4.33 \mathrm{~b}$ & $10.80 \mathrm{c}$ & $30.16 \mathrm{c}$ \\
\hline \multirow{2}{*}{$\begin{array}{l}\text { Beans }+S . \text { viridis }+ \text { C. olitorius } \\
+ \text { C. album root fresh }\end{array}$} & 12.50 & $5.10 \mathrm{e}$ & $10.88 \mathrm{e}$ & $5.39 \mathrm{~d}$ & $2.85 \mathrm{de}$ & $8.48 \mathrm{de}$ & $25.42 \mathrm{e}$ \\
\hline & 25.00 & $5.63 \mathrm{~d}$ & $12.65 \mathrm{~d}$ & $5.80 \mathrm{c}$ & $3.41 \mathrm{c}$ & $10.78 \mathrm{c}$ & $29.30 \mathrm{~cd}$ \\
\hline \multirow{2}{*}{$\begin{array}{l}\text { Beans }+S . \text { viridis }+ \text { C. olitorius } \\
+ \text { C. album root dry }\end{array}$} & 4.95 & $4.99 \mathrm{e}$ & $10.50 \mathrm{e}$ & $4.88 \mathrm{e}$ & $2.75 \mathrm{de}$ & $7.20 \mathrm{e}$ & $24.90 \mathrm{e}$ \\
\hline & 9.90 & $5.50 \mathrm{~d}$ & $11.53 \mathrm{e}$ & $5.26 \mathrm{~d}$ & $3.11 \mathrm{c}$ & $9.36 \mathrm{~d}$ & $27.84 \mathrm{~d}$ \\
\hline LSD at $5 \%$ & & 0.37 & 1.11 & 0.36 & 0.34 & 0.90 & 2.14 \\
\hline
\end{tabular}

$\mathrm{N} / \mathrm{A}=$ not applicable; mean values in the same column for each trait followed by the same lower-case letter are not significantly according to Fisher's Least Significant Difference (LSD) test at $\mathrm{p} \leq 0.05$ 
Table 4. Total polyphenois and total flavenoids in leaf and root extracts of Chenopodium album

\begin{tabular}{ccc}
\hline Part of the plant & $\begin{array}{c}\text { Total polyphenol } \\
\text { [mg gallic acid/100 g dry weight] }\end{array}$ & $\begin{array}{c}\text { Total flavonoids } \\
\text { [mg rutin/100 g dry weight] }\end{array}$ \\
\hline Leaves & 550.00 & 1,880 \\
Roots & 171.22 & 590 \\
\hline
\end{tabular}

Table 4 shows that the total polyphenol and flavonoid content in the leaves of $C$. album was greater than that in the root. The quantity of polyphenols and flavonoids in the leaves was triple or even higher than that found in the root.

\section{Discussion}

Many plant products are known to inhibit germination and growth of other plants. Therefore, these products can be a possible tool for controlling weeds and may be used as natural herbicides (Mahmood and Cheema 2004; Singh et al. 2005).

The results of the current study reveal that spraying different extracts of C. album, significantly inhibited the growth of $S$. viridis and C. olitorius associated with beans in comparison to the untreated, unweeded control (Table 1).

The phytotoxic effects of Chenopodium spp. have been well documented by Szaryas (2000); Alam et al. (2002); Batish et al. (2006); Rezaie and Yarnia (2009); Shahrokhi et al. (2011); Abdul Majeed and Muhammad (2012) and Bagheri et al. (2013). The phytotoxic inhibition of the extracts on weed growth may be attributed to the presence of some allelochemicals in the extracts. It has been found that C. album extract contains some allelochemicals such as cinnamic acid amide alkaloid as a racemic mixture, named chenoalbicin 1 (Cutillo et al. 2004), some phenolic compounds and lignan (Cutillo et al. 2006).

In this current work we used fresh leaves and roots and their corresponding dry materials, so the differences between fresh and dry materials are not due to the quantity of materials but to the type of the extract.

The results also show that the inhibition of weed growth depended on the extracted plant organ, whether it was leaf or root, fresh or dry, as well as its concentration. The leaf extract showed the highest inhibition effect at $25 \%$. The data also indicate that C. olitorius (broad leaf weed) was more susceptible to allelopathic leaf and root extract of C. album than S. viridis (grass weed). The inhibition in both weed growth was consistant during the experimental period in comparison to two untreated weed species associated with beans (unweeded control). Previous studies carried out by our group using fresh and dry leaf extracts have shown specific inhibitory activity against weeds especially spraying with fresh leaf extract (El-Rokiek and Eid 2009; El-Rokiek and El-Nagdi 2011). Mallik et al. (1994); Mojab et al. (2003); Hegazy and Farrag (2007) found that the aerial part of Chenopodium spp. contain flavonoids, saponins and tannins. Our results were confirmed by Chatterjee et al. (2012). Vaidya et al. (2014) attributed the differences between fresh and dry tissues to the thermostability of flavonoid groups during leaf drying and extract preparation.
In the current work the chemical analysis of both leaf and root extract was found to contain polyphenols as well as flavonoids (Table 4). The results in Table 4 point out that the total polyphenol and flavonoid content in the leaves of $C$. album highly exceeded that in the root. The quantity of polyphenols and flavonoids in the leaves was triple, or even higher than that determined in the root. Hence, a correlation between higher amounts of total polyphenols, flavonoid content and weed growth inhibition may be associated with a potential allelopathic property of C. album. This may explain the more inhibitory effect of leaf extract on weed growth than that of root extract. ElKhatib et al. (2004) obtained similar results. Several workers attributed the inhibition in weed growth by different plant extracts to the presence of some allelochemicals such as phenols, flavonoids and/or alkaloids (Chon and Kim 2004; El-Rokiek and Eid 2009; Ghareib et al. 2010; ElRokiek and El-Nagdi 2011; El-Rokiek et al. 2014).

It was observed that there are great differences between the percentage of reduction in dry weight of $S$. viridis in pots of the untreated, unweeded control (pots that contain beans and the two weed species) and that treated with Chenopodium extracts as compared to untreated pots that contain S. viridis alone (Table 1). The percentage of reduction in dry weight of S. viridis reached $91.17 \%$ at harvest with $25 \%$ leaf extract and $9.37 \%$ in the untreated control. The corresponding results in C. olitorius were 96.31 and 24.39. This indicates that the reduction in weed growth may be primarily attributed to the allelopathic effect of C. album extracts and not to competition between weeds.

The reduction in the growth of both weeds in treated pots decreased their competition against beans and accordingly this reduction was accompanied by increases in bean growth. The increase in the growth of beans was reflected in the increase of both green and dry yield which was represented by the number of green pods, weight of green pods, the number of dry pods, the number of seeds/pod, seed yield/plant and weight of 100 seeds (Tables 2 and 3). It has often been reported that controlling weeds decreased the competition of weeds against crops and consequently increased growth and yield of the crop plants (Ngouajio et al. 1997; Blackshaw et al. 2000; El-Metwally et al. 2010; El-Rokiek et al. 2013).

\section{Conclusions}

This work indicates that fresh leaf and root extracts of C. album are potential bioherbicides against $S$. viridis and C. olitorius. The leaf extract of C. album, which contains many more polyphenols and flavonoids than the root extract, was more effective than root extract against the two weeds and increased bean yield. Future studies will be required to better understand the difference between the effects of leaf and root fractions. 


\section{Acknowledgements}

The authors are thankful to Agricultural Research Centre, Egypt, for providing the seeds of this experiment. The authors indebted to the National Research Centre, Egypt, for the provision of the laboaratories and facilitating this work.

\section{References}

Abdul Majeed Z.C., Muhammad Z. 2012. Allelopathic assessment of fresh aqueous extracts of Chenopodium album $\mathrm{L}$. for growth and yield of wheat (Triticum aestivum L.). Pakistan Journal of Botany 44 (1): 165-167.

Alam S.M., Khan S.M.M., Shereen A. 2002. Influence of aqueous leaf extract of common lambsquarters and $\mathrm{NaCl}$ salinity on the germination, growth, and nutrient content of wheat. Acta Physiologiae Plantarum 24 (4): 359-364.

Bagheri A., Rezaei M., Eivazi A.R. 2013. Allelopathic properties of Chenopodium album on seedling related traits of sorghum cultivars. International Journal of Agronomy and Plant Production 4 (S): 3743-3747.

Batish D.R., Singh H.P., Rana N., Kohli R.K. 2006. Assessment of allelopathic interference of Chenopodium album through its leachates, debris extracts, rhizosphere and amended soil. Archives of Agronomy and Soil Science 52 (6): 705-715.

Blackshaw R.E., Molnar L.J., Henning Muendel H., Saindon G., Xiangju L.I. 2000. Integration of cropping practices and herbicides improves weed management in dry bean (Phaseolus vulgaris). Weed Technology 14 (2): 327-336.

Chatterjee S., Chatterjee S., Bhattacharya A., Dutta S. 2012. Allelopathic effect of Cassia occidentalis leaves on mustard seeds. Trends in Biotechnology Research 1 (1): 29-35.

Chon S.U., Kim Y.M. 2004. Herbicidal potential and quantification of suspected allelochemicals from four grass crop extracts. Journal of Agronomy and Crop Science 190 (2): 145-150.

Cutillo F., D'Abrosca B., DellaGreca M., Zarrelli A. 2004. Chenoalbicin, a novel cinnamic acid amide alkaloid from Chenopodium album. Chemistry and Biodiversity 1 (10): 1579-1583.

Cutillo F., DellaGreca M., Gionti M., Previtera L., Zarrelli A. 2006. Phenols and lignans from Chenopodium album. Phytochemical Analysis 17 (5): 344-349.

El-Khatib A.A., Hegazy A.K., Galal H.K. 2004. Does allelopathy have a role in the ecology of Chenopodium murale? Annales Botanici Fennici 41 (1): 37-45.

El-Metwally I.M., El-Rokiek Kowthar G., Ahmed S.A., El-Desoki E.R., Abd-Elsamad E.E.H. 2010. Effect of adding urea or ammonium sulphate on some herbicides efficiency in controlling weeds in onion plants. Journal of American Science 6 (11): 536-543.

El-Rokiek Kowthar G., Eid R.A. 2009. Allelopathic effects of Eucalyptus citriodora on amaryllis and associated grass weed. Planta Daninha 27 (Numero Especial): 887-899.

El-Rokiek Kowthar G., El-Nagdi W.M. 2011. Dual effects of leaf extracts of Eucalyptus citriodora on controlling purslane and root-knot nematode in sunflower. Journal of Plant Protection Research 51 (1): 121-129.

El-Rokiek Kowthar G., Abdelhamid M.T., Saad El-Din Samia A. 2013. Physiological response of purslane weed (Portulaca oleracea) and two common beans (Phaseolus vulgaris) re- combinant inbred lines to Phosphorus fertilizer and bentazon herbicide. Journal of Applied Sciences Research 9 (4): 2743-2749.

El-Rokiek Kowthar G., Saad El-Din Samia A., Sharara Faida A.A. 2010. Allelopathic behaviour of Cyperus rotundus L. on both Chorchorus olitorius (broad leaved weed) and Echinochloa crus-galli (grass weed) associated with soybean. Journal of Plant Protection Research 50 (3): 174-179.

El-Rokiek Kowthar G., Saad El-Din Samia A., Messiha Nadia K., Sharara Faida A.A. 2014. Effect of guava leaf residue on broad and narrow leaved weeds associated wheat plants. International Journal of Agricultural Research 9 (7): 356363.

Ghareib H.R., Abdelhamed M.S., Ibrahim O.H. 2010. Antioxidative effects of the acetone fraction and vanillic acid from Chenopodium murale on tomato plants. Weed Biology and Management 10 (1): 64-72.

Graham P.H., Rosas J.C., Jensen C.E. De, Peralta E., Tlusty B., Acosta-Gallegos J., Pereira P.A.A. 2003. Addressing edaphic constraints to bean production: the Bean/Cowpea CRSP project in perspective. Field Crop Research 82 (2-3): 179-192.

Hamayun M., Hussain F., Afzal S., Ahmad N. 2005. Allelopathic effect of Cyperus rotundus and Echinochloa crus-galli on seed germination, and plumule and radicle growth in maize (Zea mays L.). Pakistan Journal of Weed Sciences Research 11 (1-2): 81-84.

Hegazy A.K., Farrag H.F. 2007. Allelopathic potential of Chenopodium ambrosioides on germination and seedling growth of some cultivated and weed plants. Global Journal of Biotechnology and Biochemistry 2 (1): 1-9.

Lehoczky E., Reisinger P. 2003. Study on the weed-crop competition for nutrients in maize. Communications in Agricultural and Applied Biological Sciences 68 (4 Pt A): 373-380.

Mahmood A., Cheema Z.A. 2004. Influence of sorghum mulch on purple nutsedge (Cyperus rotundus L.). International Journal of Agriculture and Biology 6 (1): 86-88.

Mallik M.A.B., Puchala R., Grosz F.A. 1994. A growth inhibitory factor from lambsquarters (Chenopodium album). Journal of Chemical Ecology 20 (4): 957-967.

Mojab F., Kamalinejad M., Ghaderi N., Vahidipour H.R. 2003. Phytochemical screening of some species of Iranian plants. Iranian Journal of Pharmaceutical Research 2 (2): 77-82.

Ngouajio M., Foko J., Fouejio D. 1997. The critical period of weed control in common bean (Phaseolus vulgaris L.) in Cameroon. Crop Protection 16 (2): 127-133.

Quettier D.C., Gressier B., Vasseur J., Dine T., Brunet C., Luyckx M.C., Cayin J.C., Bailleul F., Trotin F. 2000. Phenolic compounds and antioxidant activities of buckwheat (Fagopyrum esculentum Moench) hulls and flour. Journal of Ethnopharmacology 72 (1): 35-42.

Rezaie F., Yarnia M. 2009. Allelopathic effects of Chenopodium album, Amaranthus retroflexus and Cynodon dactylon on germination and growth of safflower. Journal of Food, Agriculture and Environment 7 (2): 516-521.

Shahrokhi S., Bagheri A., Jamshidi S. 2011. Tolerance of five sorghum cultivars to different concentrations of common lambsquarters (Chenopodium album) leaf aqueous extracts. p. 61-65. In: The 3rd International Conference on Chemical, Biological and Environmental Engineering, ICBEE, Vol. 20. IACSIT Press, Singapore, China, 23-25 September 2011, 120 pp. 
Singh H.P., Batish D.R., Kaur S., Kohli R.K. 2003. Phytotoxic interference of Ageratum conyzoides with wheat (Triticum aestivum). Journal of Agronomy and Crop Science 189 (5): 341-346.

Singh N.B., Pandey B.N., Singh A. 2009. Allelopathic effects of Cyprus rotundus extract in vitro and ex vitro on banana. Acta Physiologiae Plantarum 31 (3): 633-638.

Singh H.P., Batish D.R., Setia N., Kohli R.K. 2005. Herbicidal activity of volatile oils from Eucalyptus citriodora against Parthenium hysterophorus. Annals of Applied Biology 146 (1): 89-94.

Singleton V.L., Orthofer R., Lamuela-Raventos R.M. 1999. Analysis of total phenols and other oxidation substrates and antioxidants by means of Folin-Ciocalteu's reagent. Methods in Enzymology 299: 152-178.

Snedecor G.W., Cochran W.G. 1980. Statistical Methods. 7th ed. The Iowa State University Press, Ames, Iowa, IA, USA, 507 pp.
Stanković S.M. 2011. Total phenolic content, flavonoid concentration and antioxidant activity of Marrubium peregrinum $\mathrm{L}$. extracts. Kragujevac Journal of Science 33: 63-72.

Szaryas I. 2000. Biology, damage and possibilities of protection of some summer annual weeds, annual mercury (Mercurias annual L.), redradicle pigweed (Amaranthus retroflexus L.), common lambsquarters (Chenopodium album) occurring in sugar beet. Ph.D. thesis. The University of Tennessee, Knoxville, USA.

Vaidya B.N., Brearley T.A., Joshee N. 2014. Antioxidant capacity of fresh and dry leaf extracts of sixteen Scutellaria species. Journal of Medicinally Active Plants 2 (3-4): 42-49.

Weston L.A. 1996. Utilization of allelopathy for weed management in agroecosytems. Agronomy Journal 88 (6): 860-866. 